\title{
Preoperative detection of gastrointestinal neuroendocrine tumors using endoscopic ultrasonography
}

\author{
M. J. Varas Lorenzo, J. M. Miquel Collell'1, M. D. Maluenda Colomer², J. Boix Valverde ${ }^{3}$ \\ and J. R. Armengol Miróo, \\ Units of Echoendoscopy and Endoscopy. Centro Médico Teknon, ${ }^{1}$ Centro Médico Delfos, ${ }^{2}$ Instituto Universitario Dexeus, \\ ${ }^{3}$ Clínica Quirón and ${ }^{4} H o s p i t a l$ Vall d’Hebrón. Universidad Autónoma de Barcelona. Barcelona, Spain
}

\begin{abstract}
Objective: almost 30\% of gastroenteropancreatic neuroendocrine tumors (GEPET) escape preoperative identification using standard imaging techniques. The goal of this retrospective study is to present our cumulative experience in the assessment of GEPET by preoperative endoscopic ultrasonography (EUS), and to compare it with a literature review.

Patients and methods: thirty-seven patients with suspected specific hormonal syndromes were sequentially examined with US, CT, MRI, angiography, OctreoScan, and radial and sectorial EUS. Sixteen were males (43\%) and 21 were females (57\%), with a mean age of 61 years (interval: 40-84 a). Of all 37 patients, 27 had 19 endocrine tumors in the pancreas and 14 tumors in their gastrointestinal tract. No tumors were demonstrated in $10 \mathrm{pa}-$ tients, hence they were used as a control group. Of all $37 \mathrm{pa}$ tients, 24 were operated on or had histological samples collected, with the presence of 26 GEPET (10 carcinoids) being confirmed in 22 patients.

Results: EUS sensitivity and diagnostic accuracy were 81\% and $78 \%$. Specificity was $80 \%$. All these values were similar to the mean values obtained from the literature review.

Three pancreatic rumors smaller than or equal to $1 \mathrm{~cm}$ (insulinomas) were detected, which had escaped diagnosis with previous US, CT, and MRI studies.

An echoendoscopic examination of the pancreas could not be completed in two cases (5\%), a pancreas carcinoid and an already gastrectomized double pancreatic gastrinoma.

Conclusion: EUS is a good preoperative technique for GEPET detection, and may likely be superior to other imaging techniques in the assessment of small tumors. The usefulness of EUS as a primary exploration after US or HCT has been posited for tumor diagnosis and localization before surgery.
\end{abstract}

Key words: Neuroendocrine tumors. Carcinoid tumors. Pancreatic endocrine tumors. Endoscopic ultrasonography. Endosonography. Echoendoscopy.

Recibido: 11-12-05.

Aceptado: 25-07-06.

Correspondencia: M. J. Varas Lorenzo. Centro Médico Teknon. C/ Marquesa Vilallonga, 12. 08017 Barcelona. Fax: 934172 302. e-mail: varas@dr.teknon.es
Varas Lorenzo MJ, Miquel Collell JM, Maluenda Colomer MD, Boix Valverde J, Armengol Miró JR. Preoperative detection of gastrointestinal neuroendocrine tumors using endoscopic ultrasonography. Rev Esp Enferm Dig 2006; 98: 828-836.

\section{INTRODUCTION}

Pancreatic endocrine tumors (PET) are benign in $40 \%$ of cases, and their size ranges from less than 1 to $5 \mathrm{~cm}$; hence, their successful diagnosis and localization before surgery are very important for a complete cure (1).

Tumors greater than $1-2 \mathrm{~cm}$ are easily detectable with modern imaging techniques (US, helical CT, MRI, OctreoScan), while those smaller than $1 \mathrm{~cm}$ (insulinomas, some gastrinomas, and patients with multiple endocrine neoplasm) should be localized with selective or provocative angiography (A), trans-hepatic percutaneous catheterization of the portal vein (TPCPV) with vein sample collection from the splenoportal axis, and intraoperative ultrasonography (IUS); even like this nearly $30 \%$ of cases cannot be identified preoperatively. Endoscopic ultrasonography (EUS) is a most recently introduced diagnostic technique (2), that could theoretically diagnose PETs smaller than $1 \mathrm{~cm}$ in diameter (minimum size detected: $3 \mathrm{~mm}$ ) localted in the head and body of the pancreas with a sensitivity of $85 \%$, as those located in the pancreatic tail would be more difficult to recognize.

Of all gastroenteropancreatic endocrine tumors (GEPETs), around 40\% are PETs and the remaining 55\% are carcinoid tumors, which are mainly identified using endoscopy. EUS may study the depth and extension of this type of neuroendocrine lesions, thus facilitating endoscopic tumorectomy or polypectomy.

The goal of this study was to present our cumulative experience in the assessment of GEPET by EUS, and to perform a review of the literature until 2005. 


\section{PATIENTS AND METHODS}

\section{Patients}

Thirty-seven patients with suspected specific hormonal syndromes (carcinoid syndrome, Zollinger-Ellison syndrome (ZES), glucagonoma, insulinoma, somatostatinoma, VIPoma, and non functional carcinoid tumor; one of them, specifically a patient with ZES, had a type I multiple endocrine neoplasia) were sequentially studied with US with or without color Doppler, CT, MRI, OctreoScan, angiography, and EUS.

Sixteen were males (43\%) and 21 were females (57\%) with a mean age of 61 years (range: $40-84$ years).

Of all 37 patients, 27 had 19 tumors in the pancreas, and 14 in their gastrointestinal tract (33 tumors).

Of all 37 patients 24 were operated on or had histological material collected, with the presence of 26 GEPETs (12 pancreatic, 14 gastrointestinal -10 carcinoids) being confirmed in 22 patients.

In 10 patients (only 2 operated on, all with long-term follow-up) no tumors were demonstrated, and these were used as a control group.

\section{Method}

EUS was initially performed using an Olympus GFUM3/ Aloka EUM3 unit with a 7.5-MHz transducer and a 30-35-mm focal length, which allows the exploration of structures within $10 \mathrm{~cm}$ with a resolution of $3 \mathrm{~mm}$. EUS was then carried out with an Olympus GF-UM20/EUM20-30 unit with a 7.5- and 12-MHz transducer including a 2-mm biopsy-aspiration channel. Focal length is 25-30 $\mathrm{mm}$, and depth is $8 \mathrm{~cm}$. More recently a radial Olympus GF-UM Q130 unit with a 7.5- and 20-MHz transducer and a 2.2-mm channel was used, as was a sectorial Olympus GF UCT160-OL5 unit with a 7.5-MHz transducer, 3.7-mm channel, and Olympus $22 \mathrm{G}$ puncture needles.

Four EUS-FNAPs were performed as per the usual technique.

Exploration methodology included all VI standard positions accepted at the EUS meeting held in Stockholm in $1982(2,3)$, with the stomach, duodenum, pancreas, and liver being examined.

Pancreatic neuroendocrine lesions are seen as hypo- or isoechogenic, homogeneous, well-delimited areas (Figs. 1 and 2).

Lesions in the gut are hypoechogenic, and are included in the first layers. Echoendoscopic suspicion led to excision (tumorectomy or polypectomy) in most cases (carcinoid tumors) (Figs. 3 and 4).

\section{Statistical method}

Precision (P), sensitivity (S), specificity (Sp), PPV, and NPV were all analyzed using standard formulas for all operated on and/or histologically confirmed tumors.

\section{RESULTS}

The ultrasonographic pattern obtained by EUS was similar to that of US: rounded, homogeneous, hypo- or isoechogenic, well-encapsulated masses or nodules with hypo- or isoechogenic borders and a maximum diameter of 0.4 to $5.0 \mathrm{~cm}$. Three pancreatic tumors equal to or smaller than $1 \mathrm{~cm}$ were identified, which had escaped detection previously with US, CT, and MRI. The smallest tumor detected was 4-mm in size.

Sensitivity and diagnostic precision were 81 and $78 \%$, respectively. PPV was $95 \%$. Sensitivity was higher for digestive tract neuroendocrine tumors $(85 \%)$ versus pancreatic neuroendocrine tumors $(75 \%)$.

The tumor but not its precise location were detected in two cases: in one it was presumably detected in the headbody, and was in fact in the tail of the pancreas; the second tumor was thought to be in the head of the pancreas, and was in fact in the duodenum.

Two false positive cases were seen among the 10 controls, and thus specificity was $80 \%$.

No echoendoscopic study of the pancreas could be successfully performed for 2 patients (5\%), both with pancreatic lesions -in a carcinoid case because of exploration intolerance, and in a ZES because of a gastrectomized dual pancreas gastrinoma. All gastrointestinal neuroendocrine tumors could be appropriately identified despite their small size, and endoscopic biopsy and/or polypectomy procedures ensued.

\section{DISCUSSION}

Almost $30 \%$ of GEPETs escape preoperative localization with the usually employed modern imaging techniques (US, CT, MRI, OctreoScan, etc.) (1). Endoscopic ultrasonography (EUS) or echoendoscoy is one of the more recently introduced diagnostic techniques to study the pancreatic ultrasonographic pattern with frequencies of 7.5 and $12 \mathrm{MHz}$. Intrapancreatic neuroendocrine tumors are usually small (insulinomas are smaller than $1 \mathrm{~cm}$ in size), and only non-secreting or non-functional growths are usually big (greater than $4 \mathrm{~cm}$ ). Lesions are hypo- or isoechogenic, well delimited, and resemble adenopathies; a differential diagnosis with mucinous tumors such as adenocarcinoma is required for cystic or irregular lesions.

The duodenum will be explored from the genu superius. These tumors usually exhibit an ultrasonographic pattern similar to that of leiomyoma involving the $2^{\text {nd }}$ and $3^{\text {rd }}$ layers, while leiomyoma usually affects the $4^{\text {th }}$ layer. Exclusion of metastatic adenopathies is important.

Heyder (4) and Bolondi (5) were first to localize and diagnose insulinomas using EUS. 


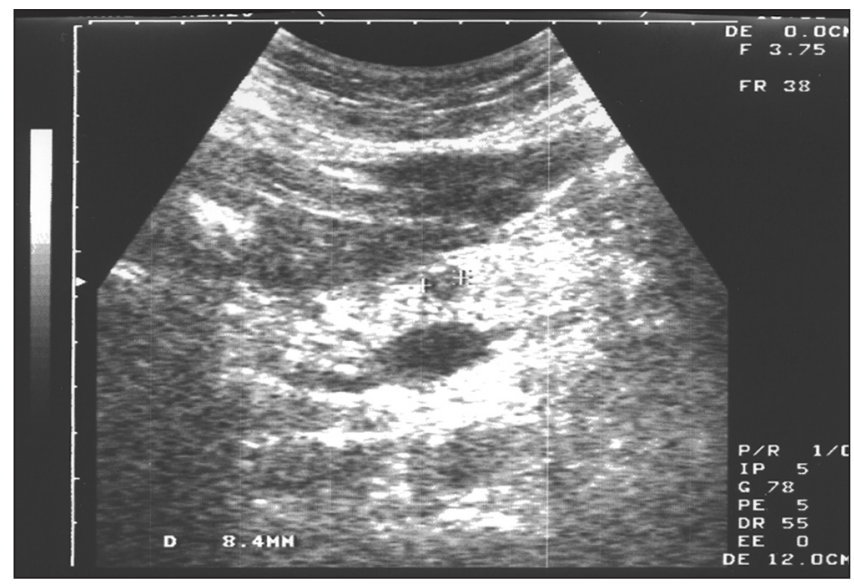

Fig. 1.- A transversal ultrasonographic section of the pancreatic area that detected a hypoechogenic nodule $8.4 \mathrm{~mm}$ in size, which stands out within the homogeneous, echogenic pancreas.

Corte transversal ecográfico sobre el área pancreática, detectando nódulo hipoecogénico de $8,4 \mathrm{~mm}$, que resalta dentro del páncreas homogéneo y ecogénico.

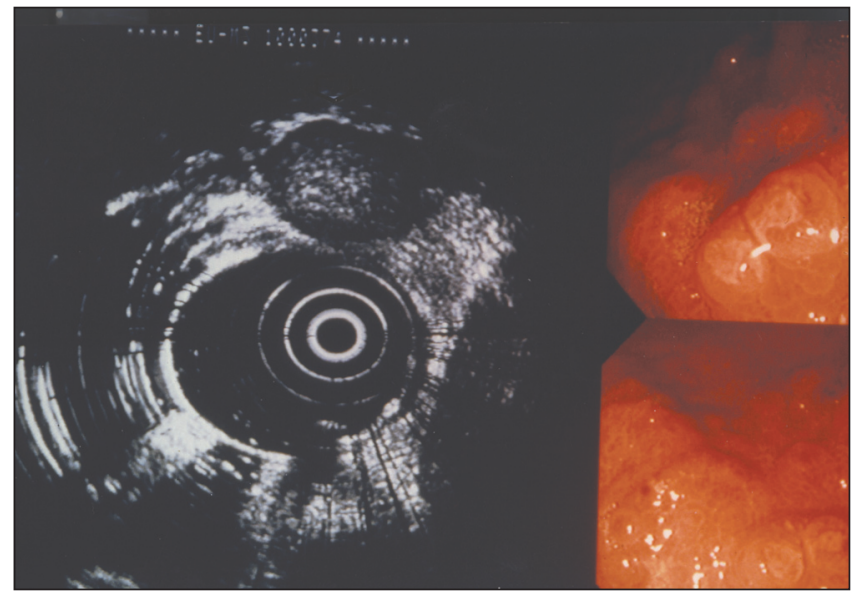

Fig. 2.- A hypoechogenic bilobulated nodule with a hyperechogenic center, and two small, lateral, satellite hypoechogenic nodules suggestive of gastrinomas. On the right, endoscopic images of gastric carcinoids (top) and duodenal gastrinomas (bottom) in a patient with MEN-I.

Nódulo bilobulado hipoecogénico, con centro hiperecogénico, y dos nodulillos hipoecogénicos satélites, laterales, sugestivos de gastrinomas. A la derecha imágenes endoscópicas de carcinoides gástricos (arriba) y gastrinomas duodenales (abajo) en un enfermo con NEM-I.

Lightdale et al. (7) detected endocrine tumors with EUS in $77 \%$ of cases, one in the duodenal wall and the rest in the pancreas. In five patients with $\mathrm{CT}$ and a negative A they detected small pancreatic tumors $0.5-2 \mathrm{~cm}$ in size.

Rösch et al. $(9,12)$ studied 37 cases with 39 endocrine tumors that remained undetected with US or CT, and which had a mean size of $1.4 \mathrm{~cm}$. EUS showed a precision and sensitivity of $82 \%$, and a specificity of $95 \%$.

We (23) have studied 20 cases, 6 without tumors and 14 patients with 22 endocrine tumors (16 operated). Sen-

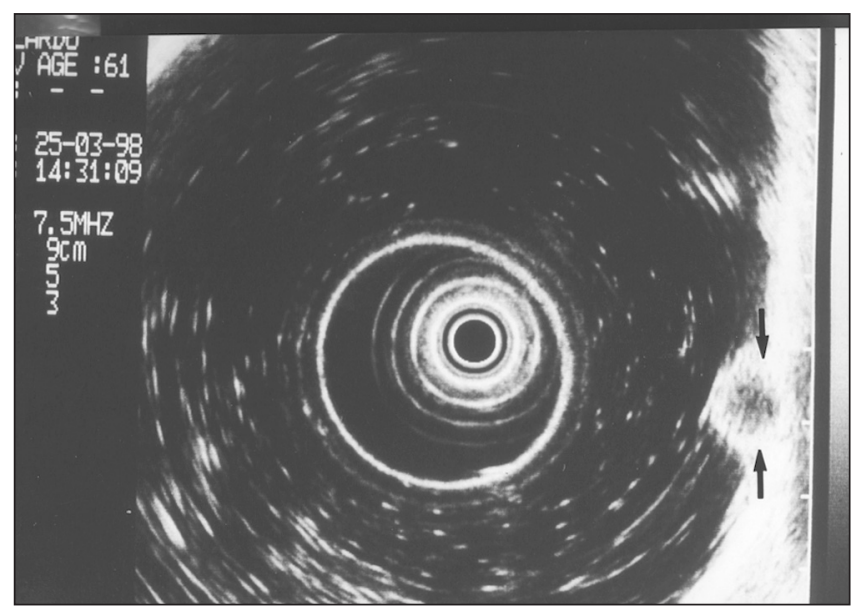

Fig. 3.- Radial EUS of a water-filled stomach revealing on the right one of the gastric carcinoids (submucosal hypoechogenic nodule) of the previous patient.

USE radial con estómago relleno de agua que demuestra a la derecha uno de los carcinoides gástricos (nódulo hiopoecogénico submucoso) del enfermo anterior.

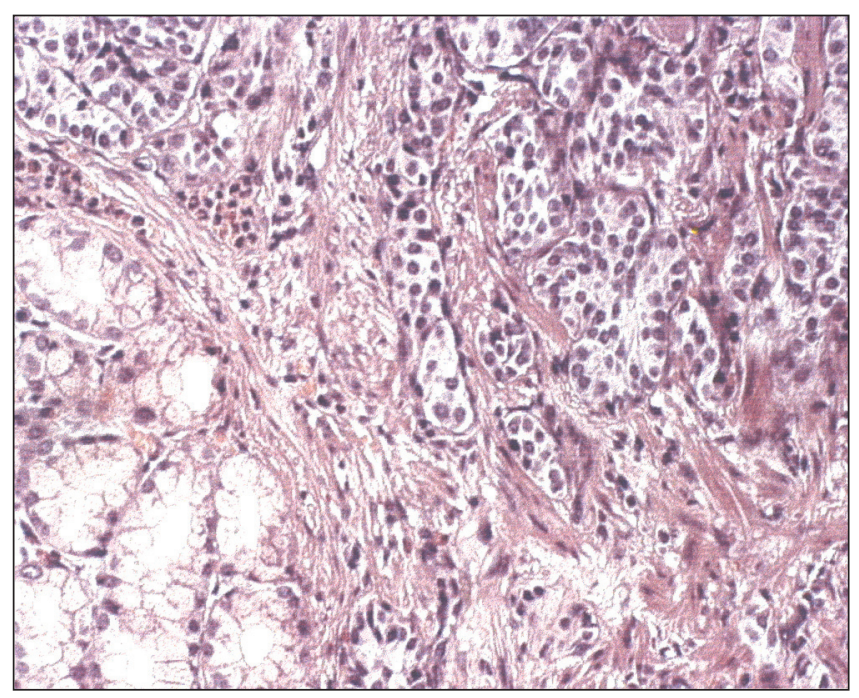

Fig. 4.- Histological image of a carcinoid after polypectomy. Imagen histológica carcinoide tras polipectomía.

sitivity was $75 \%$, and specificity was $83 \%$. These values were superior to those obtained with other imaging techniques in the multicenter study by Rösch et al. (12), and in our literature review (7-23). Mean sensitivity was $81 \%$ (higher for insulinomas versus gastrinomas), and mean specificity was $85 \%$. Also, results currently obtained with 37 cases were superior to those from our historic series. We believe that EUS is nowadays superior to the remaining imaging techniques particularly in the diagnosis of small tumors. 
Table I. Reviews performed

\begin{tabular}{ll}
\hline Rösch and Classen (9) until 1991, 30 cases & S: $90 \%$ \\
& \\
Zimmer (32) 2000, 11 studies & S: $88 \%$ \\
Insulinomas & S: $81 \%(57-92)$ \\
Gastrinomas & S: $70 \%(40-100)$ \\
& \\
Varas et al. until 2005, 21 studies & S: $81 \%$ Sp: $85 \%$ \\
Insulinomas & S: $82 \%(57-100)$ \\
Gastrinomas & S: $74 \%(30-100)$ \\
\hline
\end{tabular}

\section{Table II. Greater series}

\begin{tabular}{|c|c|c|c|c|}
\hline Palazzo et al. (11) & $\begin{array}{l}32 \mathrm{c} . \\
12 \mathrm{i} . \text { operated } \\
7 \mathrm{~g} . \text { operated }\end{array}$ & & $\begin{array}{c}\text { S: } 87 \% \\
77 \% \\
100 \%\end{array}$ & \\
\hline Rösch et al. (12) TC - & $\begin{array}{l}37 \text { operated with } 39 \mathrm{~T} \text {. } \\
31 \text { insulinomas }\end{array}$ & $P: 82 \%$ & $\begin{array}{l}82 \% \\
80 \%\end{array}$ & Sp: $95 \%$ \\
\hline De Angelis et al. (22) & 32 c. (18 operated) & & $83 \%$ & \\
\hline Carpenter et al. (29) & $\begin{array}{l}57 \mathrm{c} .44 \text { operated } \\
22 \mathrm{i} . \\
22 \mathrm{~g} .\end{array}$ & $\begin{array}{l}89 \% \\
77 \%\end{array}$ & $\begin{array}{l}83 \% \\
76 \% \\
100 \%\end{array}$ & $\begin{array}{l}100 \% \\
100 \%\end{array}$ \\
\hline Anderson et al. (33) & $\begin{array}{l}82 \text { c. } 61 \text { operated } \\
\text { Insulinomas } \\
\text { Gastrinomas }\end{array}$ & $93 \%$ & $\begin{array}{c}93 \% \\
88 \% \\
100 \%\end{array}$ & $95 \%$ \\
\hline Gouya et al. (44) & $\begin{array}{l}30 \text { c. } 32 \text { i. EUS } \\
\text { EUS }+C T\end{array}$ & & $\begin{array}{c}94 \% \\
100 \%\end{array}$ & \\
\hline Varas et al. & $37 c$. & $78 \%$ & $81 \%$ & $80 \%$ \\
\hline
\end{tabular}

We detected three pancreatic tumors (insulinomas) smaller than or equal to $1 \mathrm{~cm}$ in size, which had not been diagnosed with US, CT or MRI.

The smallest detected case was $4 \mathrm{~mm}$ in size.

We thought that the diagnostic strategy should be as follows: US-CT-MRI-O as first-line tests, EUS or A as second-line tests for non-located tumors, and finally EUS-assisted laparotomy or laparoscopy.

Two tumors were also identified each in one patient, but their precise location was missed.

EUS could not be fully carried out in $5 \%$ of cases: in one case because of test intolerance; in the other because the patient was gastrectomized.

In conclusion, we think that EUS is a good preoperative technique for GEPET detection, and will possibly be superior to other imaging techniques, including helical $\mathrm{CT}$, for small-size tumors; hence it must become a primary technique for the diagnosis location, and staging of these rare tumors, even for their histopathologic diagnosis (24-28).

Santo et al. (28) studied 76 cases, and performed an FNAP in $96 \%$ of them, with a precision of $94 \%$.

EUS sensitivity is higher in studies most recently reported (29-34), approaching that of EUS-FNAP.
Carpenter et al. (29) studied 57 cases with both radial and sectorial equipment, and obtained similar results: 44 operated, 22 gastrinomas, and 22 insulinomas. Total sensitivity and precision were $83 \%$ and $89 \%$, higher for gastrinomas versus insulinomas (S: 100 versus 76\%).

Anderson et al. (33), with the widest series ever published (82 pancreatic cases with a mean $1.51 \mathrm{~cm}$ in size) obtained a precision and sensitivity of $93 \%$, and a specificity of $95 \%$, much higher than those obtained in the multicenter study by Rösch (12). Gastrinomas were identified in $100 \%$, and insulinomas in $88 \%$ of cases. Most benign tumors were hypoechogenic and homogeneous.

In the study by Ardengh (31) sensitivity for preoperative insulinoma location (12 cases) was $83 \%$ for EUS versus $17 \%$ for HCT.

Another distinct subject is the study of MEN (35-37), where neuroendocrine tumors are usually very small -their lower bound is currently $3 \mathrm{~mm}$ (34). In our case, these measured $5 \mathrm{~mm}$.

Anyway, novel technologies (intraductal EUS with miniprobes, color EUS, PET, etc.) may eventually change all these approaches; for example, a case has been reported that was diagnosed by intraductal EUS, and conventional EUS had previously provided a false negative result (38); of late (39) power Doppler and color Doppler were compared to somatostatin scintigraphy (OctreoScan) in 29 patients, finding a sensitivity of 94 versus $54 \%$, and a specificity of 96 versus $81 \%$ in differentiating between neuroendocrine tumors and other pancreatic lesions.

In a comparative study (40) in 18 patients, EUS had the highest sensitivity (88\%), OctreoScan had 52\%, and they both were more sensitive than CT, US, or MRI (24$36 \%)$. For 17 pancreatic tumors EUS had a much higher sensitivity versus OctreoScan (94 vs. 47\%).

Upon analyzing cost-effectiveness (41) (2,620 versus 4,846 dollars per patient) in the preoperative location of 36 pancreas endocrine tumors a diagnostic strategy has ultimately been suggested where EUS would be performed first-line, in contrast to previous strategies (23) positing the US-HCT-MRI-OctreoScan string for first-line diagnosis, and the reserving of EUS for second-line diagnosis in cases with non-located tumors; intraoperative ultrasounds (IUS) would then be used during surgery, as EUS and IUS are the most sensitive techniques according to most recent reviews $(32,42,43)$.

In a latest paper reporting on 30 patients with 32 pancreas insulinomas EUS sensitivity was $94 \%$ (30/32), but sensitivity increased to $100 \%$ when EUS plus CT were used as a diagnostic strategy (44) (Tables I and II).

\section{REFERENCES}

1. Varas MJ. Tumores endocrinos pancreáticos. En: Pajares JM, editor. Temas actuales en Aparato Digestivo 2. Tomo II. Barcelona: Dispharm S.A. 1994. p. 557-76. 
2. Sivak MV Jr, George C. Endoscopic ultrasonography: preliminary experience. Scand J Gastroenterol 1984; 19 (Supl. 94): 51-9.

3. Caletti GC, Bolondi L, Zani L, Labó G. Technique of endoscopic ultrasonography investigations: Esophagus, stomach and duodenum. Scan J Gastroenterol 1986; 21 (Supl. 123): 1-5.

4. Heyder N. Localization of an insulinoma by ultrasonic endoscopy. N Engl J Med 1985; 312: 860-1.

5. Bolondi L, LiBassi S, Gaiani S, Campione O, Marrano D, Barbara L. Diagnosis of islet cell tumor by means of endoscopic ultrasonography. J Clin Gastroenterol 1990; 12: 218-21.

6. Rösch T, Lorenz R, Braig C, Siewert JR, Classen M. Preoperative localization of endocrine tumors of the pancreas: endoscopic ultrasound is superior to transabdominal sonography and computed tomography (abstract). Gastrointest Endosc 1990; 36: 199200.

7. Lightdale CJ, Botet JF, Woodruff JM, Brennan MF. Localization of endocrine tumors of the pancreas with endoscopic ultrasonography. Cancer 1991; 68: 1815-20.

8. Yamada M, Komoto E, NaitoY, Tsukamoto Y, Mitake M. Endoscopic ultrasonography in the diagnosis of pancreatic islet cell tumors. J Ultrasound Med 1991; 23: 85-7.

9. Rösch T, Classen M. Endoscopic ultrasonography. In: Cotton PB, Tytgat GNJ, Williams CB, editors. Annual of gastrointestinal endoscopy. London: Current Science Ltd, 1992; 67-80.

10. Palazzo L, Roseau G, Chaussade M, et al. Preoperative localization of pancreatic endocrine tumors by endoscopic ultrasonography (EUS). Gastroenterology 1992; 102: A 284.

11. Palazzo L, Roseau G, Salmeron M. Endoscopic ultrasonographyy in the preoperative localization of pancreatic endocrine tumors. Endoscopyy 1992; 24 (Supl. 1): 350-3.

12. Rösch T, Lightdale CJ, Botet JF, Boyce GA, Sivak MV Jr, et al. Localization of pancreatic endocrine tumors by endoscopic ultrasonography. N Engl J Med 1992; 326: 1721-6.

13. Glover JR, Shorvon PJ, Lee WR. Endoscopic ultrasound for localization of islet cell tumors. Gut 1992; 33: 108-10.

14. Ruszniewski P, Amouyal P, Amouyal G, et al. Diagnostic value of endoscopic ultrasonography (EUS) for the localization of gastrinomas. Gastroenterology 1993; 104: A331.

15. Ruszniewski P, Amouyal P, Amouyal G, et al. Endoscopic ultrasonography (EUS) in the localization of insulinomas: Results of a multicentre prospective study. Gastroenterology 1993; 104: A 332.

16. Varas MJ, Boix J, Armengol JR. Valor de la ecografía endoscópica en el diagnóstico de los tumores endocrinos pancreáticos y gastroduodenales. Rev Esp Enferm Dig 1994; 85: 354-8.

17. Thompson NW, Czako PF, Fritts LL, et al. Role of endoscopic ultrasonography in the localization of insulinomas and gastrinomas. Surgery 1994; 116: 1131-8.

18. Bansal R, Kochman ML, Bude R, et al. Localization of neuroendocrine tumors utilizing linear-array endoscopic ultrasonography. Gastrointest Endosc 1995; 42: 76-9.

19. Schumacher B, Lübke HJ, Strohmeyer G, Starke AAR. Prospective study on the detection of insulinomas by endoscopic ultrasonography. Endoscopy 1996; 28: 273-6.

20. Ueno N, Tomiyama T, Tano S, et al. Utility of endoscopic ultrasonography with color doppler function for the diagnosis of islet cell tumor. Am J Gastroenterol 1996; 91: 772-6.

21. Zimmer T, Stolzel U, Bader M, et al. Endoscopic ultrasonography and somatostatin receptor scintigraphy in the preoperative localization of insulinomas and gastrinomas. Gut 1996; 39: 562-8.

22. De Angelis C, Repici A, Arena V, Pellicano R, Rizzetto M. Preoperative Endoscopic Ultrasonography in decision making and management for pancreatic endocrine tumors: A 6-year experience. Endoscopy 1998; 30 (Sup. 1): A 182-6.

23. Varas MJ, Armengol JR, Boix J, Maluenda MD, Pou JM. Diagnóstico y localización preoperatoria de los tumores endocrinos digestivos mediante ultrasonografía endoscópica. Gastroenterol y Hepatol 1999; 22: 223-6.

24. Rathod VD, Binmoeller KF, Thul R, et al. The role of EUS-guided fine needle aspiration- biopsy (FNAB) in the diagnosis of neuroendocrine tumors. Endoscopy 1997; 29: E 25.

25. Ciaccia D, Al-Assi M, Wiersema MJ, et al. Preoperative localization and diagnosis of pancreatic and peripancreatic islet cell tumors using endoscopic ultrasound (EUS) guided fine needle aspiration (FNA): A multicenter experience. Gastroenterology 1998; 114: A 449 (G1824).

26. Voss M, Hammel P, Molas G, Palazzo L, Dancour A, et al. Value of endoscopic ultrasound guided fine needle aspiration biopsy in the diagnosis of solid pancreatic masses. Gut 2000; 46: 244-9.

27. Gress FG, Barawi M, Kim D, Grendell JK. Preoperative localization of a neuro endocrine tumors of the pancreas with EUS-guided fine needle tattooing. Gastrointest Endosc 2002; 55: 594-7.

28. Santo E, Kariv R, Monges G, Marmor S, Giovannini M. The role of linear array endoscopic ultrasound with fine-needle aspiration in the diagnosis and preoperative evaluation of pancreatic neuroendocrine tumors-experience with 76 cases. Gastrointest Endosc 2002; 56 (4): S118.

29. Carpenter SL, Bansal R, Nostrant TT, Elta GH, Thompson N, Scheiman JM. Accuracy of endoscopic ultrasound in pancreatic neuroendocrine tumor localization (abstract). Gastroenterology 1996; 110: A381.

30. Pitre J, Soubrane O, Palazzo L, Chapuis Y. Endoscopic ultrasonography for the preoperative localization of insulinomas. Pancreas 1996; 13: 55-60.

31. Ardengh JC, Maluf Filho F, Rosenbaum P, Ganc AJ, Goldenberg A, et al. Role of endoscopic ultrasonography in preoperative localisation of insulinomas-Brazilian experience. Endoscopy 2000; 32: A33 P85.

32. Zimmer T, Scherübl H, Faiss F, et al. EUS of neuroendocrine tumors. Digestion 2000; 62: 45-50.

33. Anderson MA, Carpenter S, Thompson NW, Nostrant TT, Elta GH, Scheiman JM. Endoscopic ultrasound is highly accurate and directs managements in patients with neuroendocrine tumors of the pancreas. Am J Gastroenterol 2000; 95 (9): 2271-7.

34. Sabbagh L, Albis R, Velasco B, Gutiérrez O, Aponte D, Oliveros R. Endoscopic ultrasonography value in the diagnosis of neuroendocrine pancreatic tumors. Gastrointest Endosc 2002; 56 (4): S117.

35. Palazzo L, Borrotto E, Napoleon B, Pujol B, Roseau G, Gimbaud R. Is endoscopic ultrasonography accurate for the localization of pancreatic and duodenal tumors in patients with multiple endocrine neoplasia type I? Gastroenterology 1994; 106: A313.

36. Meroni E, Bareggi E, Colombo P, Genovese S, Travaglini P, Malesci A. Diagnostic evaluation of pancreas including endoscopic ultrasound in multiple endocrine neoplasia type I syndrome. Gastrointest Endosc 2002; 56 (4): S117.

37. Gauger PG, Scheiman JM, Wamsteker EJ, et al. Role of endoscopic ultrasonography in screening and treatment of pancreatic endocrine tumors in asymptomatic patients with multiple endocrine neoplasia type 1. Br J Surg 2003; 90: 748-54.

38. Menzel J, Domschke W. Intraductal ultrasonography may localize islet cell tumours negative on endoscopic ultrasound. Scand J Gastroenterol 1998; 33: 109-12.

39. Rickes S, Unkrodt K, Ocran K, Neije H, Wermke W. Differentiation of neuroendocrine tumors from other pancreatic lesions by echo-enhanced power doppler sonography and somatostatin receptor scintigraphy. Pancreas 2003; 26 (1): 76-81.

40. Zimmer T, Ziegler K, Bader M, et al. Localisation of neuroendocrine tumours of the upper gastrointestinal tract. Gut 1994; 35: 471-5.

41. Bansal R, Tierney W, Carpenter S, Thompson N, Sheiman JM. Cost effectiveness of EUS for preoperative localization of pancreatic endocrine tumors. Gastrointest Endosc 1999; 49: 19-25.

42. Jensen RT, Norton JA. Tumores endocrinos del páncreas. En: Enfermedades Gastrointestinales y Hepáticas (I), Sleisenger and Fordtran. Buenos Aires: Ed. Médica Panamericana; 2004. p. 1045-74.

43. Fritscher-Ravens A. Endoscopic ultrasonography and neuroendocrine tumor of the pancreas. J O Pancreas 2004; 5: 273-81.

44. Gouya H, Vignaux O, Augui J, Dousset B, Palazzo L, et al. CT, endoscopic sonography, and combined protocol for preoperative evaluation of pancreatic insulinomas. AJR 2003; 181: 987-92. 